\title{
Enriching The Learning Experience In Upper Level Business Law
}

Diane Y. Hughes, Rowan University, USA

\begin{abstract}
This paper is a brief explanation of one method used to engage student participation and facilitate learning in an upper level business law course.
\end{abstract}

Keywords: teaching, instruction, learning, cases, case method, business, business law, legal, legal environment, law, accounting, accountants, creditor, debtor, credit card, wills, estates, lemon law, interview

\section{INTRODUCTION}

C $\mathrm{n}$ this paper, I describe the usage of enrichment exercises in a senior level business law course of accounting majors. The name of the course is Law for Accountants. It is the second and final business law course required of accounting majors and is completed in the junior or senior year. The purpose of the course is to give students exposure to some topics not taught in the freshmen level Legal Environment of Business class that they may encounter on the CPA examination.

A problem that I have experienced in teaching an upper level business law course is that after three or four years of studying accounting, these students either have no interest or lack the necessary skills for success in answering subjective questions and analysis. Having spent years "looking for the correct answer" in accounting, they tend to think they must do the same in law. The first day of class, I warn students that there may not always be a right or wrong answer but the key is in supporting their conclusions with the law.

A few years ago, I began experimenting with requiring students to participate in real life examples of the application of the law, sometimes in area outside of the scope of the subject matter. Not being sure how this additional requirement would be received, I assigned a score of only $10 \%$ of the final grade; more points were added if students presented their findings in class.

The result was that the students were more attentive in class when studying or covering the material assigned and many expressed appreciation for the information learned in outside assignments.

Students were given a choice of experiences and required to submit a report of 5 choices. The assignments were as follows:

1. Obtain a credit card contract application. Read the provisions and determine whether you would become a debtor. Write a 1-2 page paper on your reasoning.

In this assignment, I was careful to use terminology used in class such as "debtor" and "contract" consistent with the subjects studied from the textbook.

2. Interview a sales representative of a RENT TO OWN type of establishment. Ask 10 questions, record the answers and determine whether you would agree to their terms.

I let the student determine the ten questions, but looked for the questions to tie into our discussions of contracts, unconscionability, sales of good, uniform commercial code. 
3. See \#2 above. Do the same assignment using a PAY DAY LOAN type of business.

4. Write a detailed description of your experience with a local bank using multiple endorsements.

This assignment is directly related to the subject covered in the course...Negotiable Instruments and Articles 3 and 4 of the Uniform Commercial Code.

5. Create a comic strip illustrating the concept of express warranty.

6. Write a 1-2 page paper discussing the two types of holders in due course.

This topic was one that required no outside initiative and could be answered by relying on the textbook.

7. Examine an auto insurance policy. What options are available if the insured's car is declared a total loss?

Remotely related to the topic of torts but requires students to examine their own policy.

8. Research the Lemon Law of any state and discuss its key points in a 2-3 page paper.

9. Prepare a will and power of attorney for a client.

10. Imagine that you are starting a business. Would you want to register a trade name? Explain why or why not. Also explain how to register a trade name.

11. Interview a real estate agent and write a 1-2 page paper on the process of purchasing a home starting with making an offer.

12. Discuss the advantages and disadvantages of $0 \%$ credit card offers.

\section{THE OUTCOME}

The most popular choices were Lemon Law (with approximately $90 \%$ of all students writing this), preparation of a will and power of attorney, and the credit card application assignments. Student participation in class increased and some made requests for more coverage of material, especially regarding the Lemon Laws. I asked students what they liked about the assignments. Of those verbally participating, they all appreciated the vibrancy of the law and how it affected their current and future decisions. Many expressed that after reading and researching some of the topics, they would never agree to them, such as some credit card offers or rent to own agreements. I also asked the students what they disliked about the assignment expecting to hear that it took too much time. Surprisingly, the students requested additional assignments and those assignments weigh heavier in their final grade calculation.

Overall, the students saw value in preparing enrichment exercises and that they learned they must read the fine print carefully.

\section{AUTHOR INFORMATION}

Diane Y. Hughes is Associate Professor, Rohrer College of Business, Rowan University, 201 Mullica Hill Road, Glassboro, New Jersey. Email address: Hughes@ rowan.edu. She has taught both accounting and business law courses since 1983. She is also a licensed attorney and CPA.

\section{REFERENCES}

1. Herreid, Clyde(1998). Return to Mars How Not to Teach a Case Study, Journal of College Science Teaching, February, 1998.

2. Lampe, Marc (2004). A New Paradigm for the Teaching of Business Law and Legal Environment Classes, ALSB Proceedings. 